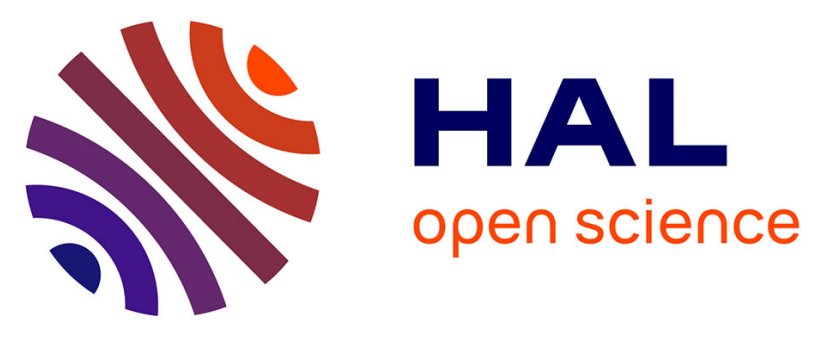

\title{
A single-center study on total mastectomy versus skin-sparing mastectomy in case of pure ductal carcinoma in situ of the breast
}

Margaux Lhenaff, Christine Tunon de Lara, Marion Fournier, Hélène Charitansky, Véronique Brouste, Simone Mathoulin-Pelissier, Vincent Pinsolles, Aurelien Rousvoal, Emmanuel Bussieres, Florence Chassaigne, et al.

\section{To cite this version:}

Margaux Lhenaff, Christine Tunon de Lara, Marion Fournier, Hélène Charitansky, Véronique Brouste, et al.. A single-center study on total mastectomy versus skin-sparing mastectomy in case of pure ductal carcinoma in situ of the breast. EJSO - European Journal of Surgical Oncology, 2019, 45, pp.950 955. 10.1016/j.ejso.2019.01.014 . hal-03486118

\section{HAL Id: hal-03486118 https://hal.science/hal-03486118}

Submitted on 20 Dec 2021

HAL is a multi-disciplinary open access archive for the deposit and dissemination of scientific research documents, whether they are published or not. The documents may come from teaching and research institutions in France or abroad, or from public or private research centers.
L'archive ouverte pluridisciplinaire HAL, est destinée au dépôt et à la diffusion de documents scientifiques de niveau recherche, publiés ou non, émanant des établissements d'enseignement et de recherche français ou étrangers, des laboratoires publics ou privés.

\section{(ㄷ)(1) $\$$}

Distributed under a Creative Commons Attribution - NonCommerciall 4.0 International 


\section{A single-center study on simple mastectomy versus skin-sparing mastectomy in case of pure ductal carcinoma in situ of the breast}

Running title: Total versus skin-saving mastectomy

Margaux Lhenaff MD ${ }^{1}$, Christine Tunon de Lara MD ${ }^{2}$, Marion Fournier MD², Hélène

Charitansky $\mathrm{MD}^{2}$, Véronique Brouste ${ }^{3}$, Simone Mathoulin-Pelissier PHD ${ }^{1-3}$, Vincent

Pinsolles PHD ${ }^{1,}$ Aurelien Rousvoal MD², Emmanuel Bussieres PHD ${ }^{1-2}$, Florence Chassaigne

$\mathrm{MD}^{4}$, Sabrina Croce MD ${ }^{4}$, Houda Ben Rejeb MD ${ }^{4}$, Gaétan MacGrogan MD 4

1 Université de Bordeaux 351 Cours de la Liberation 33400 Talence

2 Institut Bergonié 229 cours de l'Argonne 33076 Bordeaux Department of Surgery

3Institut Bergonié 229 cours de l'Argonne 33076 Bordeaux Department of Biostatistics

4 Institut Bergonié 229 cours de l'Argonne 33076 Bordeaux Department of Pathology

\section{Corresponding Author:}

\section{Dr. Christine Tunon de Lara}

Institut Bergonié, Comprehensive Cancer Centre,

229 cours de l'Argonne,

33076 Bordeaux, France.

e-mail:c.tunondelara@bordeaux.unicancer.fr

Funding: This study did not receive any funding

Conflict of Interest: The authors declare no conflict of interest.

\section{ABSTRACT}




\section{Introduction}

Ductal carcinoma in situ (DCIS) accounts for $15 \%$ of all breast cancers and generally, the prognosis is good if treated optimally. The standard treatment includes breast conservative surgery along with adjuvant radiotherapy. Skin-sparing mastectomy (SSM) preserves the breast skin envelope but its oncological safety poses a few concerns. Moreover, no DCISspecific studies have compared the local recurrence (LR) rate following total mastectomy (TM) or SSM. We evaluated the LR rate in DCIS patients who underwent either TM or SSM.

Methods: This is a retrospective study on women who underwent mastectomy with or without immediate breast reconstruction or secondary reconstruction for pure DCIS of the breast. All patients treated at Institut Bergonié by mastectomy for DCIS from January 1990 to December 2010 were included. LR and overall survival (OS) rates were estimated.

Results: The study population included 399 patients who were categorized into two groups, 207 in the TM group and 192 in the SSM group. At 10 years of follow-up, the LR rate was $0.97 \%$ in the TM group and $1.04 \%$ in the SSM group ( $\mathrm{p}=\mathrm{NS}$ ). The OS of the entire population was $94.7 \%$ [95\% CI; 91.6 - 96.7], 92.8\% [95\% CI, 87.9 - 95.8] for the TM group and $96.8 \%$ [95\% CI, 91.6 - 98.8] for the SSM group.

Conclusions: In our study, the LR rate following mastectomy is low, regardless of the surgical technique used, with an excellent OS at 10 years.

\section{INTRODUCTION}

Ductal carcinoma in situ (DCIS) is characterised by the proliferation of malignant cells within the galactophoric ducts, without invasion through the basal membrane. DCIS lesions are mostly subclinical, usually discovered by mammography and/or mammary ultrasound 
performed during breast cancer screening. In 2011, DCIS accounted for $15 \%$ of all breast cancers detected, or about 6,500 new cases per year in France (1).

Treated optimally, the prognosis for DCIS is very good with an overall survival (OS) rate at 10 years $>95 \%$ (2). However, when treated conservatively, the recurrence rate for DCIS can reach up to $15 \%$ at 10 years, occurring in more than $50 \%$ of cases as an invasive carcinoma (2). Although less frequent, recurrences may also occur following initial treatment by mastectomy; a 3\% local recurrence (LR) rate at 10 years after total mastectomy (TM) was reported by Stuart et al (3).

The standard treatment for DCIS consists of breast conserving surgery (BCS) associated with adjuvant radiotherapy (RT) of the mammary gland. However, this might not always be feasible resulting in $30 \%$ of DCIS cases being treated by mastectomy (4). Mastectomy is usually recommended in case of extensive lesions in relation to the breast volume, multifocality or multicentricity, and if the patient prefers so (2). In case of mastectomy, there is no indication for complementary adjuvant therapy, in particular no indication for RT. This is favourable for an immediate breast reconstruction (IBR), at the same time as the mastectomy. The first skin-sparing mastectomy (SSM) was described in 1991 by Toth and Lappert (5). This surgical technique preserves the breast skin envelop and the infra-mammary fold. The nipple-areola complex is resected. The aesthetic result in IBR is superior to delayed reconstructions $(6,7)$.

However, concerns persist regarding the oncological safety of SSM. Although there are many studies on SSM, no DCIS-specific studies have compared the rate of local recurrence (LR) following TM and SSM. 
The primary aim of this study was to evaluate the LR rate in patients with pure DCIS treated with TM versus SSM. The secondary aims were the evaluation of the rates of loco-regional (LRR) and distant metastasis (DM).

\section{METHODS}

\section{Patients}

This is a retrospective study on women with pure DCIS of the breast who underwent mastectomy with or without immediate breast reconstruction or secondary reconstruction. All patients treated and operated on at Institut Bergonié, Bordeaux, between January 1990 and December 2010 were included.

The indications of mastectomy were: extensive DCIS or significant extension of DCIS compared to the breast size, multicentric DCIS, positive margins $<2 \mathrm{~mm}$ after BCS, and the patient's preference.

A history of prior infiltrating breast cancer, previous ipsilateral DCIS, association with microinvasive or invasive carcinoma, prophylactic mastectomy for familial BRCA mutation or for high-risk family history of breast cancer and male gender, were exclusion criteria.

\section{Surgical techniques}

All patients treated by mastectomy in Institut Bergonié for DCIS during the described period were considered for inclusion in the study. Women underwent TM or SSM. The nipple-areola complex was not conserved in any patient. No patient had adjuvant therapy.

The surgical technique for TM consisted of the excision of the mammary gland, the skin and the nipple-areola complex by Patey incision. Superficial dissection can proceed in a relatively avascular plane between the skin and the mammary gland: The Cooper's ligaments plane. For 
deeper dissections, the superficial fascia of the pectoral muscle was shaved. TM was performed when patient declined immediate reconstructive surgery. For SSM, skin and the infra-mammary fold were preserved. In order to able to relieve au IBR. Cutaneous incision was made so as to carry only the nipple-areola complex. The plane of dissection for the excision of the gland was the same as in TM: planes of the Cooper's ligaments and the fascia superfisalis. The thickness of the mastectomy flap should be the same in TM, and as uniform as possible. Immediate reconstruction techniques performed after SSM were the latissimus dorsi myocutaneaous flap and / or the use of breast prosthesis (definitive or expander). In this comparative study, we defined two groups: total mastectomy with or without delayed reconstructive surgery (the TM group) versus SSM and immediate breast reconstructive surgery (the SSM group).

Stating margin status in the surgical pathology report started in 2007.Prir to that, margin status was only mentioned if it was invaded or close to $<1 \mathrm{~mm}$ and absence of margin status $>2 \mathrm{~mm}$ was considered save.

\section{Definition of recurrence and follow-up}

LR was defined as histologically confirmed in situ or invasive breast carcinoma occurring in the ipsilateral chest wall, subcutaneous tissue or skin. LRR was defined as a recurrence in the drainage areas of the initial lesion i.e. ipsilateral axillary, internal mammary, supra clavicular and infra-clavicular nodes. Other locations of recurrence were classified as distant metastasis (DM).

For OS, all causes of death were considered as events. The participation time was calculated between the date of the first surgery and death occurrence, or date of the last news (censored data). Follow-up was stopped in August, 2016. Monitoring data was retrospectively collected 
from patients' medical files at Institut Bergonié. For patients who were no longer followed at the institute, data were obtained by a letter to the general practitioner and/or to the gynaecologist of the patient. Missing data were completed from questionnaires sent to the patients. In the absence of answer, death of the patients was ascertained by consulting the National registries.

\section{Statistical analysis}

Follow-up was calculated using the reverse Kaplan-Meier method. The Kaplan-Meier method was used for survival assessment, and the log-rank test was used to compare survival between the two groups. Due to the difference in follow-up of the two groups, only the first 10 years are taken in account.

\section{RESULTS}

From $1^{\text {st }}$ January, 1990 to $31^{\text {st }}$ December, 2010, 499 patients underwent a mastectomy for pure DCIS determined by pre-operative biopsy.

One hundred patients were excluded: 29 due to a previous history of infiltrating ipsilateral or controlateral breast cancer, 18 due to a concomitant invasive or micro-invasive carcinoma in the same breast, three due to a history of prior ipsilateral DCIS, one due to mastectomy refusal, five were men, 42 patients were operated on in another institution, one patient due to massive pulmonary embolism with immediate post-operative death, and one patient due to the lack of follow-up data.

The study population included 399 patients: who were categorized into two groups, 207 in the TM group and 192 in the SSM group. Patient's characteristics at the time of diagnosis are described in Table 1. The mean age was 55.3 years (range, 30-85). 
No patient had adjuvant therapy except for one, who benefited from hormonal therapy (Tamoxifen).

After a median follow-up of 12.9 years, 7 patients experienced a recurrence. There were four LR: two each in the TM (0.97\%) and SSM (1.04\%) groups (Table 2). In the TM group, one of the recurrences occurred 54 months after initial treatment (patient 1) and corresponded to a grade II invasive carcinoma of no special type (NST). The other recurrence (patient 2) occurred 69 months after initial treatment however, we do not its precise histology, as the patient was cared for in another institution for this recurrence.

Regarding the SSM group, both recurrences were grade III invasive carcinoma NST and occurred 48 months and 62 months after the initial surgery (patients 3 and 4), respectively (Table 3). Three patients developed LRR or DM during follow-up (Table 4). One patient, in the SSM group, presented grade II invasive carcinoma NST LRR 84 months after initial surgery (patient 5). Two patients (one in each group) developed DM, 45 months and 188 months later, respectively (patients 6 and 7). These two patients died of metastatic breast cancer. In total, 34 patients died during follow-up, 17 during the first 10 years of follow-up. Deaths that occurred beyond 10 years were not taken into account in the prognostic analysis. Of the 17 deaths, one was secondary to the evolution of the patient's initial breast pathology (patient 6). Sixteen out of 17 patients died of another disease other than breast cancer.. No deaths occurred in patients with LR.

Thirty-three patients $(8.3 \%)$ had close or positive margins, $\leq 2 \mathrm{~mm}: 8$ in the TM group and 25 in the SSM group. Three hundred and sixty-six patients $(91.7 \%)$ had negative margins $>2$ mm. Patients with close or positive margins did not receive any additional treatment. No recurrence was observed in patients with a positive margin. 
. The OS of the entire population at 10 years was $94.7 \%$ [95\% CI, $91.6-96.7]$.

The Kaplan-Meier curve illustrating OS in the TM and the SSM group is shown in Figure 1. The 10-year survival for TM group was 92.8\% [95\% CI, 87.9-95.8], and 96.8\% [95\% CI, 91.6 - 98.8] for the SSM group. There is no statistically significant difference between the two groups regarding OS (log-rank test, $\mathrm{p}=0.058)$.

\section{DISCUSSION}

In this series, with a median follow-up of 12.9 years, the LR rate is $0.97 \%$ in the TM group, and $1.04 \%$ in the SSM group ( $p>0.05)$.

The LR rate after TM is consistent with data available in the literature. Indeed, after an average follow-up of 4.5 to 12 years, the reported LR rate following TM without reconstruction for pure DCIS varies from $0.9 \%$ to $3 \%(8,9)$. There is very little data in the literature regarding the LR rate following SSM in pure DCIS. Available reports show LR rates from 0 to $3.8 \%$ after a median follow-up of 36 to 126 months (Table 5). Most of these studies are retrospective studies, with short-term follow-up and an insufficient sample size compared to the frequency of the event (i.e. LR after SSM and IBR for DCIS). To the best of our knowledge, there is no study comparing SM with SSM in patients with pure DCIS in terms of LR and OS. Timbrell et al. (20) compared LRR rates following TM and SSM in patients with DCIS. They found that the LRR rate was higher in the SSM group: after a median follow-up of 65 months, LRR rate at 5 years was $0 \%$ in the TM group, and $5.9 \%$ in the SSM group ( $\mathrm{p}=0.012)$. However, in this study, $9.5 \%$ of the patients $(19 / 199)$ had DCIS with micro-invasion. If the risk of lymph node invasion in pure DCIS at the time of diagnosis 
is less than $1 \%$ (4) then, the incidence increases if DCIS is associated with micro-invasive foci, ranging from 3-10\% (21). The prognosis of DCIS with micro-invasion is less favourable than that of pure DCIS with an increased risk of invasive LR (21). Moreover, the primary endpoint of the study of Timbrell et al., was LRR and not LR. With respect to the oncological safety of SSM followed by IBR, it is necessary to only compare LR rates in SSMs and TMs. Indeed, according to Romics et al., LRR appears to be a sequel of the aggressive tumour biology, rather than inadequate surgery (12); whereas the LR rate mirrors only the quality of the SSM oncosurgical technique.

There are no randomized controlled trials on TM versus SSM for pure DCIS. However, this will probably never be accomplished, for feasibility reasons.

The theoretical increase of LR rates in SSM is due to the presence of more residual breast tissue after this procedure as compared to TM. Indeed, whatever the surgical technique, mastectomies leave Residual glandular Breast Tissue (RBT). This is seen more often in SSMs than in TMs, where there might be RBT in the inframammary fold and behind the breast skin (corresponding to the skin flap which is preserved in SSM and would have been excised in TMs). Studies evaluating RBT following TM reported that $25 \%$ of patients have microscopic RBT foci which represents $<0.2 \%$ of the total resected breast volume (22). Regarding SSM, there is little data on RBT and the results of the studies differ with RBTs in 6-59.5\% of the patients $(23,24)$. According to Torresan et al., the presence of RBT is significantly associated with skin flaps thicker than $5 \mathrm{~mm}$ (24). Of note, leaving a skin flap thickness of less than 5 $\mathrm{mm}$ after SSM could decrease blood supply in that area which may result in increased risk of skin necrosis. The presence of RBT could question the safety of SSM. However, the risk of LR is not only associated with the presence of RBT, but also with other DCIS prognostic 
factors. Furthermore, studies show equivalent rates of local disease control in SSMs compared to TMs for pure DCIS, suggesting no oncologic implications of RBT (table 5).

In our series, the four LRs occurred after a median interval of 4.8 years (range, 4-5.8). This is consistent with data in the literature as seen in the study by Rashtian et al., where in the median interval to recurrence was 3.5 years (25). Carlson et al., reported a mean disease-free interval until LR of 4.3 years (19). Late occurrence of an invasive cancer on the chest wall following mastectomy for pure DCIS has also been described. Chan et al., reported that only one LR occurred at 2 years in 59 patients with DCIS and one invasive carcinoma of the chest wall, 20 years following mastectomy (26). They considered this lesion to be a new cancer, arising in RBT, due to the long interval between the new lesion and the first surgery. However, this is only one case-report. Not many reports on late-occurring invasive chest wall lesions (more than 10 years) after mastectomy for pure DCIS have been described, highlighting the importance of a prolonged follow-up. In our cohort, the low number of events does not make it possible to highlight prognostic factors for recurrence. Even though the LR rate in pure DCIS treated with mastectomy is low, many studies have investigated the risk factors for recurrences (invasive in most cases) $(27,28)$. Their aim was to identify a subset of patients who may benefit from a more aggressive treatment. Several studies have shown that young age at diagnosis, close or positive resection margins, and high nuclear grade are associated with an increased risk of LR in patients treated with conservative surgery (with or without RT) $(2,29)$. However, the impact of these prognostic factors on mastectomy-treated DCIS is less consistent, with contradictory results.

Young age at initial diagnosis has been reported as an independent prognostic factor of LR for patients who underwent BCS, despite being defined differently in various studies ( $\leq 40$ years, $<45$ years or 50 years $)(30,31,32,33)$. We have shown in a previous study that women under 
40 years of age with DCIS have a higher risk of LR and a less favourable prognosis than women over 40: relative risk of 1.82 [95\% CI, 1.03-3.24] $(\mathrm{p}=0.041)(30,34)$. Regarding patients treated with mastectomy, the results of the studies diverge. Owen et al., found an LRR rate at 10 years in 55 patients $\leq 40$ years of $7.5 \%$ versus $1.5 \%$ in patients aged over 40 years $(\mathrm{p}=0.003)(35)$. Conversely, Klein et al., and Carlson and et al., have found no statistically significant difference in the LR rate according to age at diagnosis $(36,19)$. Regarding the nuclear grade, a meta-analysis by Wang and et al., that included 10,526 patients, found a statistically significant increase in LR in the case of high-grade nuclear lesion treated by BCS with or without RT or by mastectomy: with a risk estimate of 1.81 [95\% CI, 1.53-2.13] (29). Studies focusing only on mastectomy do not observe this.

After 61 months of follow-up, a study of Rashtian et al., found four LRs in 16 patients (25\%) with high grade DCIS and close resection margins $(<2 \mathrm{~mm})$ versus one LR in 12 patients $(8 \%)$ with DCIS grade I or II and close margins (25). However, this result is not significant as other studies have not found an association between high nuclear disease and greater risk of LR or LRR $(14,18,35,36)$. This contradictory result may correspond to a lack of power due to the fact that these studies are retrospective, single-institution and on a small study sample size. In patients with pure DCIS treated by BCS with or without RT, one of the most significant prognostic factors for LR is the resection margin status (26). From this data, one could generalise this to patients treated with mastectomies. However, results of studies on the LR rate based on margins in mastectomy for DCIS are discordant. Indeed, some studies find an increased risk of LR in case of positive or close margins, while others have not shown any differences in LR rate based on margin status (Table 6). These differences may be due to the fact that studies evaluating the impact of margin status on the LR occurrence are difficult to compare as the definition of close margins varies according to the author (from 1-10 mm). In addition, these studies are limited: due to the small number of patients included in the studies, 
a short follow-up and a low occurrence of events. Rashtian et al., found a LR rate after a median follow-up of 61 months of $16 \%$ with positive or close margins less than $2 \mathrm{~mm}$, versus $2 \%$ when the margins were between $2-10 \mathrm{~mm}(\mathrm{p}=0.036)(25)$. However, other authors did not find any statistically significant difference in the LR rate based on margin status (Table 6).

In our study, 33 patients had positive or close margins $(\leq 2 \mathrm{~mm})$ and none of these patients experienced LR after a median follow-up of 7.9 years.

The other prognostic factors for LR described in the literature (i.e., necrosis, large tumour size and multifocality) are contradictory, and there is little data about these factors in mastectomies. The 2015 French National Institute of Cancer (INCa) report reminds that lesion size and multifocality must be taken into account as they have an effect on the surgical procedure and accordingly one must adapt the surgical technique to obtain negative margins (2).

Some studies have investigated the use of post-mastectomy RT (PMRT) in patients with high LR risk after mastectomy for DCIS. Rashtian et al., suggest that PRMT could be useful in patients with margins $\leq 2 \mathrm{~mm}$ and who have another risk factor such as high nuclear grade, comedo necrosis or age $\leq 60$ years (25). Carlson et al., report that re-excision of close mastectomy margins should be performed, if possible, and PMRT should be considered (19). According to Fitz-Sullivan et al., PMRT is not warranted, except for patients with multiple close or positive margins that cannot be surgically excised (15).

Other authors do not warrant PMRT as it would have a limited benefit in view of the low rate of recurrence and due to difficulty in defining a subset of patients with a higher LR risk (26, 36, 37). Furthermore, RT has long-term adverse effects, such as second malignancies and coronary artery disease. Hence, it would be preferable to limit its indications, especially in 
young patients. Additionally, PMRT would affect the aesthetic result in patients with IBR (38, 39).

In France, INCa and the French Society of Senology and Breast Pathology (SFSPM) do not recommend PMRT (2). Similarly, the European Society for Medical Oncology (ESMO) does not recommend RT of the chest wall following mastectomy for DCIS (40).

\section{CONCLUSION}

DCIS were treated by mastectomy in $30 \%$ of patients and most of them had an immediate reconstructive surgery. SSM is being used by more and more surgeons. However, no results of randomized controlled studies comparing TM and SSM are available to date.

In our study, the LR rate following mastectomy is low, regardless of the surgical technique used, with an excellent OS at 10 years of $94.7 \%$. Furthermore, SSM with IBR allows a better aesthetic result. There is no significant difference between TM and SSM, and oncological safety is guaranteed in both techniques. SSM should therefore be considered in case of mastectomy for DCIS.

\section{ACKNOWLEDGEMENTS}

The authors thank Dr. Ravi Nookala of Institut Bergonié for the medical writing service.

\section{REFERENCES}

1. Performance de la mammographie dans le dépistage organisé des cancers du sein Synthèse de l'enquête. Collection Etudes et enquêtes, ouvrage collectif édité par l'INCa, Boulogne-Billancourt, avril 2014. 
2. Prise en charge du carcinome canalaire in situ / Questions d'actualité, Recommandations et référentiels, INCa, septembre 2015.

3. Stuart KE, Houssami N, Taylor R, Hayen A, Boyages J. Long-term outcomes of ductal carcinoma in situ of the breast: a systematic review, meta-analysis and meta-regression analysis. BMC Cancer. déc 2015 ;15(1).

4. Cutuli B, Lemanski C, Fourquet A, Lafontan B de, Giard S, Lancrenon S, et al. Carcinomes canalaires in situ (CCIS). Caractéristiques histopathologiques et traitement: analyse de 1 289 cas. Bulletin du Cancer. mars 2010;(3):301-310.

5. Toth BA, Lappert P. Modified Skin Incisions for Mastectomy: The need for plastic surgical input in preoperative planning. Plastic and reconstrutive surgery. 1991;87(6):1048 53.

6. Reefy S, Patani N, Anderson A, Burgoyne G, Osman H, Mokbel K. Oncological outcome and patient satisfaction with skin-sparing mastectomy and immediate breast reconstruction: a prospective observational study. BMC Cancer. déc 2010;10(1)

7. Al-Ghazal SK, Fallowfield L, Blamey RW. Comparison of psychological aspects and patient satisfaction following breast conserving surgery, simple mastectomy and breast reconstruction. European Journal of Cancer. oct 2000;36(15):1938 43.

8. Kelley L, Silverstein M, Guerra L. Analyzing the Risk of Recurrence after Mastectomy for DCIS: A New Use for the USC/Van Nuys Prognostic Index. Annals of Surgical Oncology. févr 2011;18(2):459 62. 
9. Chadha M, Portenoy J, Boolbol SK, Gillego A, Harrison LB. Is There a Role for Postmastectomy Radiation Therapy in Ductal Carcinoma In Situ ? International Journal of Surgical Oncology. 2012;2012:1 5.

10. Doddi S, Singhal T, Kasem A, Desai A. A single institution experience with skin sparing mastectomy and immediate breast reconstruction. The Annals of The Royal College of Surgeons of England. juill 2011;93(5):382 4.

11. Yi M, Kronowitz SJ, Meric-Bernstam F, Feig BW, Symmans WF, Lucci A, et al. Local, regional, and systemic recurrence rates in patients undergoing skin-sparing mastectomy compared with conventional mastectomy. Cancer. 1 mars 2011;117(5):916 24.

12. Romics L, Chew BK, Weiler-Mithoff E, Doughty JC, Brown IM, Stallard S, et al. Tenyear follow-up of skin-sparing mastectomy followed by immediate breast reconstruction. British Journal of Surgery. juin 2012;99(6):799 806.

13. Missana MC, Laurent I, Germain M, Lucas S, Barreau L. Suivi carcinologique à long terme de 400 mastectomies conservatrices d'étui cutané. Journal de Chirurgie Viscérale. oct 2010;147(5):402 10 .

14. Van Mierlo DRJ, Lopez Penha TR, Schipper RJ, Martens MH, Serroyen J, Lobbes MBI, et al. No increase of local recurrence rate in breast cancer patients treated with skinsparing mastectomy followed by immediate breast reconstruction. The Breast. déc 2013;22(6):1166 70.

15. FitzSullivan E, Lari SA, Smith B, Caudle AS, Krishnamurthy S, Lucci A, et al. Incidence and Consequence of Close Margins in Patients with Ductal Carcinoma-In Situ Treated 
with Mastectomy: Is Further Therapy Warranted? Annals of Surgical Oncology. déc 2013;20(13):4103 12.

16. Slavin SA, Schnitt SJ, Duda RB, Houlihan MJ, Koufman CN, Morris DJ, et al. Skinsparing mastectomy and immediate reconstruction: oncologic risks and aesthetic results in patients with early-stage breast cancer. Plastic and reconstructive surgery. 1998;102(1):49-62.

17. Spiegel AJ, Butler CE. Recurrence following Treatment of Ductal Carcinoma in Situ with Skin-Sparing Mastectomy and Immediate Breast Reconstruction: Plastic and Reconstructive Surgery. févr 2003;111(2):706 11.

18. Greenway RM, Schlossberg L, Dooley WC. Fifteen-year series of skin-sparing mastectomy for stage 0 to 2 breast cancer. The American Journal of Surgery. déc 2005;190(6):933 8.

19. Carlson GW, Page A, Johnson E, Nicholson K, Styblo TM, Wood WC. Local Recurrence of Ductal Carcinoma in Situ after Skin-Sparing Mastectomy. Journal of the American College of Surgeons. mai 2007;204(5):1074 8.

20. Timbrell S, Al-Himdani S, Shaw O, Tan K, Morris J, Bundred N. Comparison of Local Recurrence After Simple and Skin-Sparing Mastectomy Performed in Patients with Ductal Carcinoma In Situ. Annals of Surgical Oncology. avr 2017;24(4):1071 6.

21. Modesto A, Gandy C, Mery E, Filleron T, Massabeau C, Izar F, et al. Carcinome canalaire in situ avec micro-invasion : spécificités anatomopathologiques et implications cliniques. Cancer/Radiothérapie. mars 2014;18(2):107 10. 
22. Barton Jr FE, English JM, Kingsley WB, Fietz M. Glandular excision in total glandular mastectomy and modified radical mastectomy: a comparison. Plastic and reconstructive surgery. 1991;88(3):389-392.

23. Dreadin J, Sarode V, Saint-Cyr M, Hynan LS, Rao R. Risk of Residual Breast Tissue after Skin-Sparing Mastectomy: Risk of Residual Breast Tissue After Skin-Sparing Mastectomy. The Breast Journal. mai 2012;18(3):248 52.

24. Torresan RZ, Santos CC dos, Okamura H, Alvarenga M. Evaluation of Residual Glandular Tissue After Skin-Sparing Mastectomies. Annals of Surgical Oncology. déc 2005;12(12):1037 44

25. Rashtian A, Iganej S, Amy Liu I-L, Natarajan S. Close or Positive Margins After Mastectomy for DCIS: Pattern of Relapse and Potential Indications for Radiotherapy. International Journal of Radiation Oncology*Biology*Physics. nov 2008;72(4):1016 20.

26. Chan LW, Rabban J, Hwang ES, Bevan A, Alvarado M, Ewing C, et al. Is Radiation Indicated in Patients With Ductal Carcinoma In Situ and Close or Positive Mastectomy Margins? International Journal of Radiation Oncology*Biology*Physics. mai 2011;80(1):25 30.

27. Barnes NLP, Ooi JL, Yarnold JR, Bundred NJ. Ductal carcinoma in situ of the breast. BMJ. 29 févr 2012;344(feb29 1):e797 e797.

28. Montgomery RC, Fowble BL, Goldstein LJ, May DP, Hoffman JP, Sigurdson ER, et al. Local Recurrence After Mastectomy for Ductal Carcinoma In Situ. The Breast Journal. nov 1998;4(6):430 6. 
29. Wang S-Y, Shamliyan T, Virnig BA, Kane R. Tumor characteristics as predictors of local recurrence after treatment of ductal carcinoma in situ: a meta-analysis. Breast Cancer Research and Treatment. mai 2011;127(1):1 14.

30. Tunon-de-Lara C, André G, MacGrogan G, Dilhuydy J-M, Bussières J-E, Debled M, et al. Ductal Carcinoma In Situ of the Breast: Influence of Age on Diagnostic, Therapeutic, and Prognostic Features. Retrospective Study of 812 Patients. Annals of Surgical Oncology. mai 2011;18(5):1372 9.

31. Donker M, Litière S, Werutsky G, Julien J-P, Fentiman IS, Agresti R, et al. BreastConserving Treatment With or Without Radiotherapy in Ductal Carcinoma In Situ: 15Year Recurrence Rates and Outcome After a Recurrence, From the EORTC 10853 Randomized Phase III Trial. Journal of Clinical Oncology. 10 nov 2013;31(32):4054 9

32. Kong I, Narod SA, Taylor C, Paszat L, Saskin R, Nofech-Moses S, et al. Age at diagnosis predicts local recurrence in women treated with breast-conserving surgery and postoperative radiation therapy for ductal carcinoma in situ: a population-based outcomes analysis. Current Oncology. 7 nov 2013;21(1):96.

33. Van der Velden APS, Peeters PHM, Koot VCM, Hennipman A. Local Recurrences After Conservative Treatment of Ductal Carcinoma-In-Situ of the Breast Without Radiotherapy: The Effect of Age. Annals of Surgical Oncology. juill 2006;13(7):990 8.

34. Tunon-de-Lara C, Lemanski C, Cohen-Solal-Le-Nir C, de Lafontan B, Charra-Brunaud C, Gonzague-Casabianca L, et al. Ductal carcinoma in situ of the breast in younger women: A subgroup of patients at high risk. European Journal of Surgical Oncology (EJSO). déc 2010;36(12):1165 71. 
35. Owen D, Tyldesley S, Alexander C, Speers C, Truong P, Nichol A, et al. Outcomes in Patients Treated With Mastectomy for Ductal Carcinoma In Situ. International Journal of Radiation Oncology*Biology*Physics. mars 2013;85(3):e129 34.

36. Klein J, Kong I, Paszat L, Nofech-Mozes S, Hanna W, Thiruchelvam D, et al. Close or positive resection margins are not associated with an increased risk of chest wall recurrence in women with DCIS treated by mastectomy: a population-based analysis. SpringerPlus. déc 2015;4(1)

37. Childs SK, Chen Y-H, Duggan MM, Golshan M, Pochebit S, Punglia RS, et al. Impact of Margin Status on Local Recurrence After Mastectomy for Ductal Carcinoma In Situ. International Journal of Radiation Oncology*Biology*Physics. mars 2013;85(4):948 52.

38. Cordeiro PG, Pusic AL, Disa JJ, McCormick B, VanZee K. Irradiation after Immediate Tissue Expander/Implant Breast Reconstruction: Outcomes, Complications, Aesthetic Results, and Satisfaction among 156 Patients: Plastic and Reconstructive Surgery. mars 2004;113(3):877 81.

39. El-Nemr M, Rimareix F, Karsenti G, Acevedo-Henao CM, El Husseiny G, Marsiglia H, et al. Reconstruction mammaire et irradiation adjuvante des cancers du sein. Cancer/Radiothérapie. juill 2012;16(4):302 8.

40. Senkus E, Kyriakides S, Ohno S, Penault-Llorca F, Poortmans P, Rutgers E, et al. Primary breast cancer: ESMO Clinical Practice Guidelines for diagnosis, treatment and followup. Annals of Oncology. sept 2015;26(suppl 5):v8 30. 
Figure 1. A Kaplan-Meier survival curve comparing overall survival in TM and SSM groups. 
Table 1. Patients' characteristics

\begin{tabular}{|c|c|c|c|}
\hline & $\begin{array}{c}\text { TM } \\
n=207\end{array}$ & $\begin{array}{l}\text { SSM } \\
n=192\end{array}$ & $\begin{array}{c}\text { All } \\
n=399\end{array}$ \\
\hline Mean age (years) & $59.6(+/-10.2)$ & $50.6(+/-9.1)$ & $55.3(+/-10.7)$ \\
\hline \multicolumn{4}{|l|}{ Nuclear grade } \\
\hline Low & $17(8.2 \%)$ & $22(11.5 \%)$ & $39(9.8 \%)$ \\
\hline Intermediate & $39(18.8 \%)$ & $47(24.5 \%)$ & $86(21.6 \%)$ \\
\hline High & $93(44.9 \%)$ & $110(57.3 \%)$ & $203(50.9 \%)$ \\
\hline NA & $58(28.0 \%)$ & $13(6.8 \%)$ & $71(17.8 \%)$ \\
\hline \multicolumn{4}{|l|}{ Margin status } \\
\hline$\leq 2 \mathrm{~mm}$ & $8(3.9 \%)$ & $25(13 \%)$ & $33(8.3 \%)$ \\
\hline$>2 \mathrm{~mm}$ & $199(96.1 \%)$ & $167(87 \%)$ & $366(91.7 \%)$ \\
\hline \multicolumn{4}{|l|}{ Hormonal status } \\
\hline Genital activity & $51(24.6 \%)$ & $92(47.9 \%)$ & $143(35.8 \%)$ \\
\hline Menopause & $144(69.3 \%)$ & $79(41.1 \%)$ & $223(55.9 \%)$ \\
\hline NA & $12(5.8 \%)$ & $21(10.9 \%)$ & $33(8.3 \%)$ \\
\hline
\end{tabular}

NA: Not available 
Table 2. Local, loco-regional and distal recurrences according to the initial surgery.

\begin{tabular}{|c|c|c|}
\hline Recurrence & TM & SSM \\
& $\mathbf{n}=\mathbf{2 0 7}$ & $\mathbf{n}=\mathbf{1 9 2}$ \\
\hline Local & $2(0.97 \%)$ & $2(1.04 \%)$ \\
\hline Loco-regional or Distal & $1(0.48 \%)$ & $2(1.04 \%)$ \\
\hline All & $3(1.45 \%)$ & $4(2.08 \%)$ \\
\hline
\end{tabular}


Table 3. Characteristics of the four local recurrence-cases

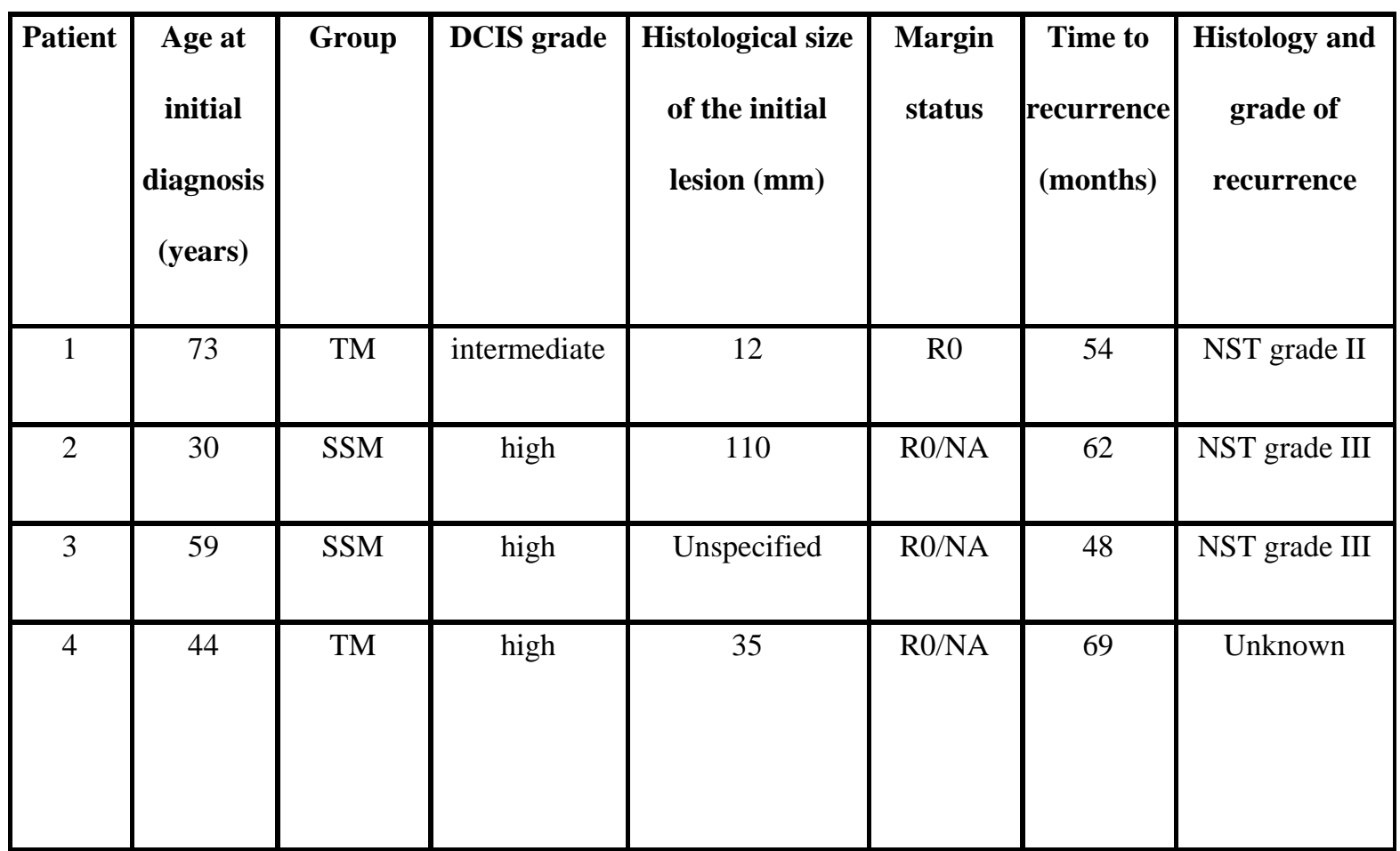

$R O=$ free margin $>2 \mathrm{~mm}$

NST: Invasive Carcinoma of no special type 
Table 4. Characteristics of loco-regional and distant recurrences

\begin{tabular}{|c|l|l|l|l|l|l|l|}
\hline Patient & Age at & Group & Recurrence & DCIS grade & Margin & Time to & Histology and \\
diagnosis & & & & & status & recurrence & grade of \\
(years) & & & & & recurrence \\
\hline 5 & 49 & SSM & LRR & high & NA & 84 & NST grade II \\
\hline 6 & 72 & TM & Distant & high & NA & 45 & NST \\
\hline 7 & 30 & SSM & Distant & intermediate & NA & 188 & NST grade II \\
\hline
\end{tabular}

NA: Not Available 
Table 5. Review of the literature on LR in pure DCIS following SSM

\begin{tabular}{|c|c|c|c|c|}
\hline Study & $\begin{array}{c}\text { Median follow-up } \\
\text { (months) }\end{array}$ & $\mathrm{N}$ & $\operatorname{LR}(\%)$ & $\mathrm{LRR}$ and $\mathrm{DM}(\%)$ \\
\hline $\begin{array}{l}\text { Reefy and al, } \\
2010\end{array}$ & 36 & 25 & 0 & 0 \\
\hline $\begin{array}{l}\text { Doddi and al, } \\
2011\end{array}$ & 58 & 30 & 0 & 0 \\
\hline Yi and al, 2011 & 53 & $\begin{array}{l}235 \text { stage } 0 \text {, } \\
\text { among them } \\
143 \text { DCIS. }\end{array}$ & 0 & $\begin{array}{l}\text { No specific data on DCIS. } \\
\text { Of } 235 \text { patients with stage } 0: 3 \\
\text { systemic recurrences. }\end{array}$ \\
\hline $\begin{array}{l}\text { Romics and al, } \\
2012\end{array}$ & 119 & 54 & 0 & DR $1.8 \%$ \\
\hline $\begin{array}{l}\text { Missana and al., } \\
2013\end{array}$ & 88 & 161 & NA & LRR $1.9 \%$ \\
\hline $\begin{array}{l}\text { Van Mierlo and } \\
\text { al., } 2013\end{array}$ & 39 & 40 & $2,5 \%$ & $\mathrm{NA}$ \\
\hline $\begin{array}{l}\text { Fitz-Sullivan } \\
\text { and al., } 2013\end{array}$ & 72 & $\begin{array}{l}810 \text { patients, } \\
\text { among them } \\
469 \text { SSM. }\end{array}$ & $\mathrm{NA}$ & $\begin{array}{l}\text { LRR : } 7 / 469 \text { or } 1.5 \% \\
25 \% \text { of patients had Tamoxifen, } \\
\text { and } 0.9 \% \text { had radiotherapy. }\end{array}$ \\
\hline $\begin{array}{l}\text { Slavin and al., } \\
1998\end{array}$ & 45 & 26 & $3,8 \%$ & 0 \\
\hline
\end{tabular}




\begin{tabular}{|l|c|c|c|c|}
\hline Spiegel and al., & 126 & 44 & 0 & 0 \\
al., 2003 & & & & \\
\hline Greenway and & 49 & 28 & 0 & NA \\
\hline Carlson and al., & 82,3 & 223 & $3,3 \%$ & $1.8 \%$ \\
\hline Timbrell et al & 96 & 102 & $5.6 \%$ & NA \\
$2016 *$ & & & & \\
\hline Present study & 120 & 192 & $1.04 \%$ & $1.04 \%$ \\
\hline
\end{tabular}

LR: Local recurrence

LRR : Loco-regional recurrence

DR : Distant metastatis

NA : Not Available

* Timbrell study : 20\% Micro invasive DCIS 
Table 6. Local recurrence rates according to the status of the resection margins after mastectomy for pure DCIS.

\begin{tabular}{|c|c|c|c|c|c|c|c|}
\hline Study & \begin{tabular}{|c|} 
Median \\
follow- \\
up \\
(months)
\end{tabular} & $\begin{array}{c}\text { Definition of } \\
\text { close or } \\
\text { positive } \\
\text { margins } \\
\text { (mm) }\end{array}$ & $\begin{array}{c}\mathbf{N}=\text { close or } \\
\text { positive } \\
\text { margins }\end{array}$ & $\begin{array}{l}\text { LR in close or } \\
\text { positive margins } \\
\text { (or LRR if LR } \\
\text { not available) }\end{array}$ & $\begin{array}{l}\mathrm{N}=\text { all } \\
\text { study }\end{array}$ & $\begin{array}{c}\text { LR rate in all } \\
\text { study } \\
\text { (or LRR if LR } \\
\text { not available) }\end{array}$ & $\mathbf{p}$ \\
\hline $\begin{array}{l}\text { Chan et al., } \\
2011 \text { (26) }\end{array}$ & 96 & $\begin{array}{l}<5 \mathrm{~mm} \\
<1 \mathrm{~mm} \\
\text { positive }\end{array}$ & $\begin{array}{l}59 \\
19 \\
4\end{array}$ & $\begin{array}{c}\text { LRR }=1.7 \% \\
0 \% \\
0 \%\end{array}$ & 59 & $\mathrm{LRR}=1.7 \%$ & \\
\hline $\begin{array}{c}\text { Rashtian et al., } \\
2008 \text { (25) }\end{array}$ & 61 & $\begin{array}{l}<10 \mathrm{~mm} \\
2.1-10 \\
<2 \mathrm{~mm}\end{array}$ & $\begin{array}{c}80 \\
\text { among } 31 \\
\text { among } 49\end{array}$ & $\begin{array}{l}2 \% \\
16 \%\end{array}$ & 80 & $7.5 \%$ & 0.036 \\
\hline $\begin{array}{c}\text { Carlson et al., } \\
2007 \text { (19) }\end{array}$ & 82.3 & $\leq 1 \mathrm{~mm}$ & 19 & $10.5 \%$ & 223 & $3.3 \%$ & 0.32 \\
\hline $\begin{array}{c}\text { Fitz-Sullivan } \\
\text { et al., } 2013 \\
(15)\end{array}$ & 76 & $\begin{array}{c}\geq 3 \\
1.1-2.9 \\
\leq 1\end{array}$ & $\begin{array}{l}709 \\
35 \\
59\end{array}$ & $\begin{array}{c}\mathrm{LRR}=0.7 \% \\
\mathrm{LRR}=3.6 \% \\
\mathrm{LRR}=5 \%\end{array}$ & 803 & $\mathrm{LRR}=1 \%$ & $\begin{array}{c}\text { NS } \\
<0.001\end{array}$ \\
\hline
\end{tabular}




\begin{tabular}{|c|c|c|c|c|c|c|c|}
\hline $\begin{array}{c}\text { Chadha et al., } \\
2012 \text { (9) }\end{array}$ & 55 & $\leq 1 \mathrm{~mm}$ & 24 & $\mathrm{LRR}=8.3 \%$ & 211 & $\mathrm{LRR}=0.9 \%$ & 0.013 \\
\hline $\begin{array}{l}\text { Klein et al., } \\
2015 \text { (36) }\end{array}$ & 121 & $\begin{array}{c}\leq 2 \\
\text { positive }\end{array}$ & $\begin{array}{l}220 \\
305\end{array}$ & $\begin{array}{l}1.4 \% \\
3 \%\end{array}$ & 1546 & $2.3 \%$ & $\begin{array}{l}0.84 \\
0.24\end{array}$ \\
\hline $\begin{array}{c}\text { Owen et al., } \\
2013 \text { (35) }\end{array}$ & 120 & $\begin{array}{c}<2 \\
\text { positive }\end{array}$ & $\begin{array}{l}35 \\
31\end{array}$ & $\begin{array}{l}\mathrm{LRR}=3.6 \% \\
\mathrm{LRR}=6.2 \%\end{array}$ & 637 & $1.00 \%$ & $\begin{array}{l}\text { NS } \\
\text { NS }\end{array}$ \\
\hline $\begin{array}{c}\text { Childs et al., } \\
2013 \text { (37) }\end{array}$ & 91.2 & $\begin{array}{c}\leq 2 \\
\text { positive }\end{array}$ & $\begin{array}{l}23 \\
21\end{array}$ & $\begin{array}{l}4.3 \% \\
4.8 \%\end{array}$ & 142 & $1.40 \%$ & \\
\hline Present study & 155 & $\overline{\leq 2}$ & 33 & $0 \%$ & 399 & $1 \%$ & $\mathrm{NS}$ \\
\hline
\end{tabular}

NS: Not Significant 


\section{Overall survival}

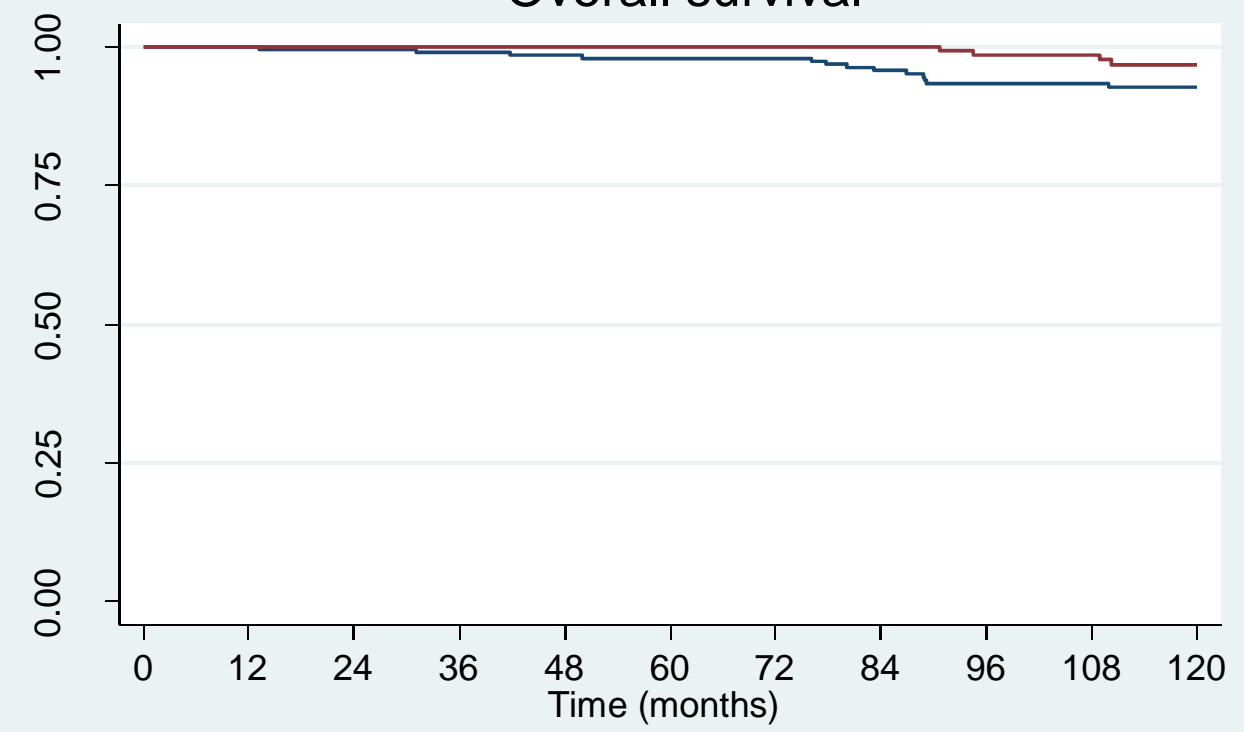

Number at risk

TM group

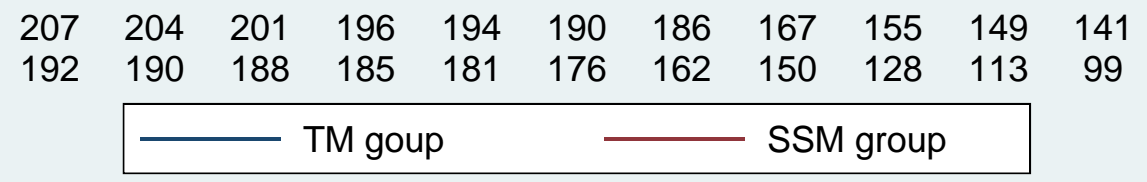




\section{Figure 2}

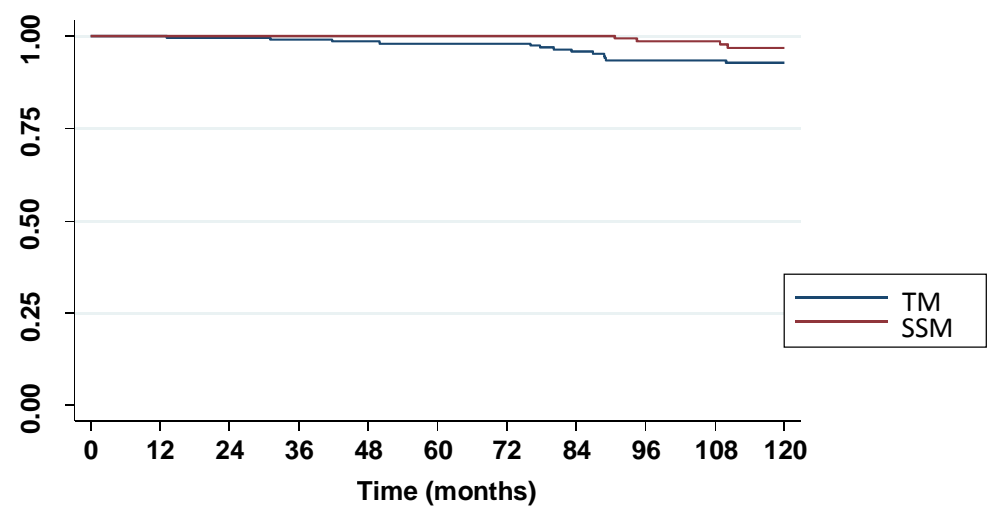

